\title{
Dramatic Aspect of Ese ifa in Yorubaland
}

\author{
Dr. Olu-Osayomi Olusegun \\ Department of Languages \& Literary Studies, Babcock University, Ilishan-Remo, Ogun State, Nigeria \\ *Corresponding Author: Dr. Olu-Osayomi Olusegun, Department of Languages \& Literary Studies, \\ Babcock University, Ilishan-Remo, Ogun State, Nigeria.Email: segunoosa@gmail.com
}

\begin{abstract}
The paper attempts an exploration of the dramatic aspect of Ese Ifa in Yorubaland with the purpose of revealing the gross under-utilization of the resources of this vital Yoruba cultural asset. And more interesting, the paper unravels the dynamics, the beauty, the uniqueness and multiple potentials of this Yoruba EseIfa. This is discussed from mythological and spiritual perspectives. Through interviews, personal experience, and observation, the paper posits that Ese Ifa plays pivotal roles in the social, religious and political milieu of the Yoruba people and has remained a rallying point. It concludes that even until today, EseIfa, with its rich dramatic features, is recognized by the Yoruba traditional body of knowledge embracing history, philosophy, medicine and folklore despite the trappings of modernization. It is expected that the paper will help in illuminating important aspects of the dynamics and significance of the Yoruba Oracle, Ifa within the context of religio-spiritual vision in the post-colonial Nigeria, in modern Africa and the globalized world.
\end{abstract}

Keywords: Yoruba, EseIfa, Ifa Oracle, Mythological, Dramatic features.

\section{Methodology}

The present paper has benefited from earlier writings on Ifa Oracle in that they have pointed the way to further analysis which is attempted here. The paper is based on the field-work which I carried out on the dramatic aspect of Eselfa in Yorubaland, the recorded samples are used in this paper. All unacknowledged quotations are from my personal collections. The recording were done on magnetic and visual tapes, and the sounds transcribed as recorded. To translate Eselfa (chapters in Ifa corpus/incantations) into English and yet preserve their exact meaning is not an easy task. I have, however, tried to meet the difficulty by being rather literal and keeping very close to the original in my translation.

\section{INTRODUCTION}

\section{1) The Yorubaland}

The Yorubaland (Yoruba: Ile-Yoruba), lies in the Southwestern part of Nigeria. Yoruba is the second largest language group in Africa, consisting of over 20 million people. The term 'Yoruba', according to Frank A.Salamone (2010:319), 'encompasses about twenty-five separate groups, each one culturally different from the other'. The people trace their origin or descent to a great ancestor, Oduduwa, who came from Ile-Ife. The bulk of the people are today found in Ogun, Ondo, Oyo, Lagos, Ekiti and substantial parts of Kwara and Kogi state bound together by language, traditions and religious beliefs and practices. Islam, Christianity, and the 'traditional' Yoruba pantheon, the Orisa, are all embraced in Yorubaland. The bond shared by all Yoruba people is the centrality of ritual to specific occasions, as well as to everyday life.

The keynote of the life of the Yoruba is their religion. However, ample information on traditional Yoruba religions exists (Talbot, 1932; Bascom, 1941; Lucas, 1948; Evans-Pritchard, 1965; Idowu, 1962; Gleason, 1973; Mbiti, 1975; Abimbola, 1976). These religions are 'primordial' among the various Yoruba communities because many of them are timeless for they are centuries old, while the beliefs and worships associated with them constitute traditional ideologies and tap roots of ethnic culture. According to Idowu (1962:5), religion forms the foundation and the all governing principle of life for them. The full responsibility of all the affairs of life belongs to the deity as far as they are concerned. 


\section{- The Yoruba Religious Identity}

Yoruba believe family in the existence of a High God commonly called Olorun or Olodumare (see Lucas, 1948:48; Idowu, 1962). He is dedicated in local folklore as creator and sustainer of life, ruler of the sky, the perfect arbiter and final Judge (Olomola, 2000:60). However, he is too passive and remote to satisfy man's immediate needs. In the words of Lucas (1948:46), "The absence of organized worship of Olorun by means of which full and uninterrupted allegiance to him could be secured has led to the worship of multitudinous gods", from major gods to minor ones. Such gods serve as intermediaries between God and men. The void thus left, according to Olomola (2000:60), is filled by a myriads for deities, Orisa, supernatural beings, anjonu, nature spirits, iwin, the ancestor, awon agba and entities such as Egungun, literally translated as masquerades.

These gods must be worshipped in appropriate places by their devotees who believe that their supplication would be answered. In pursuance of the same line of argument, Ogunba (2010:191) remarks:

The god in the traditional Yoruba or African society was closer. He monitored more closely than the Christian God or the Muslim God. The Muslim/Christian God has been described by anthropologists as a Deus remotus, the remote god. Some call him Deus otiosus, a lazy God, who retires, who is in the sky and doesn't care much about what human beings are doing. But in our traditional society, we could call on our god to come and do something and in many cases, he comes periodically. Agemo god, for example, comes every year and stays in the community for a whole month, so you can lodge all your complaints. You can call him to help you punish somebody who has offended you and so on. Because of these factors, morality was stricter than we find now.

Thus, religion in the words of Adebowale (2000:23), is "a way through which man communicates with or hopes to have relations with that which lies behind the world of their ordinary experience". Hence, religion has continually dominated the life of the Yoruba.

\section{- Origin and Role of Orunmila Deity in Yorubaland}

In the pantheon of Yoruba divinities, Orunmila is one of the higher or benevolent primordial divinities. Other outstanding divinities are Orisa-nla, Olokun, Ogun, Esu (Elegbara), Sango, Oya and Osun. Oral traditions also emphasize the part played by Orunmila in guiding the destinies of the divinities and of men. Orunmila is one of the earliest Yoruba divinities that are said to derive their power directly from 'Olodumare' or 'Olorun' ( the Supreme Being, or God; the sustainer and upholder of the universe). Orunmila is one of the six primordial divinities and even the most popular that came down to earth from Olodumare. Orunmila is a contraction of Orun-l'omo-a-ti-la (only heaven knows the means of salvation). Orunmila, otherwise known as god of divination, or the 'presiding spirit of those capable of a prescient probing into the unknown, the unanticipated (Maduakor, 1987:XII), is the divinity who assist 'Olodumare' in matters pertaining to omniscience and wisdom.

Traditionally, the Yoruba believe that Olodumare has endowed Orunmila with special wisdom and knowledge to the end that he may be His accredited representative in matters relating to man's destiny: Orunmila possessess intimate knowledge of matters affecting human destiny. One reason given for his intimate knowledge of matters affecting human destiny is that he was fully present during the time when man was being created which was also the time when each individual's destiny was sealed. Thus, Orunmila can predict the future as well as prescribing remedies for any eventuality. It is in the light of this that Idowu (1962:77) affirms:

Orunmila knows all the secrets about man. This is why he is called eleriipin (the witness or advocate of destiny).Olumoran Okan ( the one that knows the secret of the mind).From the shady to the mysterious, nothing is beyond revelation to him.In fact, the reason why a man adopts Orunmila (as his divinity) is either to make sure that his happy lot is preserved or that an unhappy lot may be rectified.

Orunmila is an important and highly regarded Yoruba divinity. For hundred years, according to Lucas (1948:62) Orunmila has made so many contributions to the culture of the people that popularity and prestige of its cult could not be overwhelmed by the increasing Christian and Islamic evangelical 
activities in West Africa. This is because he is universally worshipped in Yorubaland and his cult is found everywhere.

\section{- Ifa Oracle}

Connected with the cult of Orunmila is the geomatic form of divination known as Ifa. Ifa is a Yoruba Oracle, the medium of Orunmila. It is a cultural practice and ritual and a link between the world of the spirit and of the living. Wole Soyinka sees Ifa as separate from Orunmila. Orunmila is for him the 'essence of wisdom', while Ifa is the 'god of divination and order' (Idanre and other Poems, 1967:37). In the epic poem, Idanre, the two gods are regarded as two separate deities (70). The study of the dramatic aspect of Ese Ifa in Yorubaland therefore assumes that Orunmila and Ifa are one and the same god. The paper takes this position having considered "most Yoruba scholars however, think Orunmila and Ifa as one and the same god" (Abimbola, 1976:3).

The above expositions become relevant in view of the fact that Orunmila is an oracle often consulted in the Yoruba setting to reveal secret things to the people. This explains why the Babalawos (Ifa Priests) are usually consulted for necessary guidance during the time of important decision. In pursuance of the same line of argument, Farrow (1926:71) remarks:

Ifa or the philosophy, knowledge, and acts of Orunmila while on earth, constitute a rather all embracing, comprehensive and uniquely pervasive system. This fact alone makes the system understandably large, of many parts, and with numerous components, covering all aspects of man's life... Orunmila, as the deity of Wisdom, embodies all knowledge and wisdom of the world: it takes, in consequence, two hundred and fifty-six (256) of his original and foundation disciples to transmit and preserve the wholeness of his primordial wisdom for the world.

For anybody wishing to understand the deeper meaning of accumulated Ifa wisdom and its structural organization, Abimbola (1976) gives a rich collection of original Ifa wisdom. The corpus are divided into volumes (ODU), which amount to 156, and chapters (Ese), whose number is so vast that it is hard to determine reliably.

In Yoruba worldview, a man is believed to consist of the physical and the spiritual aspects. 'the body is the physical' while 'the spirit is the immaterial and the moral part of a man'. Oriinu (inner head) is perceived as the social force of man's behavior' (Ogungbile, 1992:20). As a result, one must consult Ifa who knows how to explain issues about the present and the future. It is in accordance with this view that Idowu (1962:5) states:

Through all the circumstances of life, through all its changing scenes, it joys and troubles, it is deity who is in control. Before a child is born, the oracle is consulted and due rites observed; when the child is born, the oracle gives directions about it; at every stage of life-puberty, betrothal, marriage, taking up a career, building a house, going on a journey and in fact, the thousand and one things which make up human existence here on earth- man is in the hands of the deity whose dictate is law, who is waiting on the other side of this life to render to him as he deserves.

Olatunji (1984:10) further emphasizes this reality:

Ifa is consulted by all Yoruba irrespective of religion, age or level of education, and when there is a major crisis, the Western educated, Christian or Muslim Yoruba, go secretly to the babalawo (Ifa priest-diviner) to know what should be done.

Ifa is the only active mouthpiece of Yoruba traditional religion taken as a whole. To the Yorubas, without Ifa the importance of other Yoruba gods would diminish. Ifa serves as an intermediary between the other gods and the people, between the people and their ancestors, and between the dead and the living. According to one saying in Yoruba 'Orisatinkoni'ba to bo Orisamiran' (Ifa is the only divinity that teaches one, how to worship other divinities). As a mouthpiece therefore, Ifa tends to popularize the other gods. Also, if a man is being punished by the other gods, he can only know this by consulting Ifa.

Ifa has always been throughout the history of the Yoruba a 'sine qua non' to life. This is because the Yoruba are rather curious about the future or what the outcome of an enterprise will be. It is in accordance with this view that Idowu (1962:5) explains: 
Before a bethrotal, before a marriage, before a child is born, at the birth of a child, and at successive stages in man's life, before a king is appointed or a chief is made or in time of crisis, in terms of sickness and at any and all times, Ifa is assurance. Like the saying 'onil'ari a o r'ola on nibaba'lawo se nd'ifal'ororun' ( it is today we see, we do not see tomorrow, hence the baba'lawo consults the oracle every fifth day).

One must therefore consult Ifa who knows how to explain issues about present and the future.

\section{- Ese Ifa}

Ifa literary corpus has two main parts: Odu (volume) and Ese (chapter). The corpus is divided into two hundred and fifty six (256) volumes called Odu: the Odu is sub-divided into numerous chapters called Ese. Olatunji (1984:118) reveals:

Ese Ifa contains statements of human problems, wishes and hopes, and a testimony to how each personage has reacted to these problems. Some of these desires are universal human needs while others are pertinent to Yoruba life. The most recurrent ones are desire for children, desire to escape death, and victory over one's adversaries.

In Ese Ifa, Olatunji further argues:

It is stated that a man choose his destiny before he comes into the world; the verses are however, silent on the point at which this choice is made, whether at conception when copulation and fertilization take place, or at birth (118).

\section{2) The Dramatic Basis of EseIfa}

In order to be able to appreciate fully the dramatic context of Ifa Oracle in Yorubaland, it is important to realize the following key points and thesis statements:

a. Dramatic performances of various forms of beauty and complexity have always been an essential ingredient of African cultural life and traditions.

b. Dramatic performances in the African traditional life could be in terms of form, ritualistic, religious, secular, mimetic, representational or expressive, according to the cultural environment, function and origin of the performance.

c. African dramatic performances are essentially socio-occasional displays

d. They provide a context, a medium for music, dance, drumming, worship and literary artistic creativity.

e. African dramatic festivals promote moral education aesthetic and artistic creativity and develop people's religious awareness, cultural sensibility and faith in the people's social institutions.

f. A fundamental function of festival drama in the African world is the promotion of the lifecontinuity of the people, their prosperity, security, fertility and safeguard from evil forces. (Akporobaro 2012: 457-458)

Also, according to Webster New Twentieth Century Dictionary of the English Language Unabridged, drama can be defined as:

A literary composition that tells a story, usually of human conflict, by means of dialogue and action, to be performed on the stage by actors; stage play; the principal forms of the drama are tragedy and comedy or modifications or combinations of these which results in the lyric drama or grand opera, melodrama, tragicomedy, opera or comic opera farce, and burlesque.

As may be seen from the above, the Oxford Dictionary of English defines Drama in terms of a literary creation that has (1) a story element (2) dialogue (3) action (4) actorsandstage, which are used for the communication of an experience real or imaginary.

Any gathering, social, clan or religious group according to Akporobaro (2012:464) has in it the ingredients and elements of theatre and drama, since it entails the communication of something, to a people. It means that burial ceremonies, marriage ceremonies, initiations, the installation of an $o b a$ or king or chief has in it the elements of drama provided it contains the elements of art and performance. 


\section{3) The Appreciation of Ese Ifa in Yorubaland- Dramatic Context}

The dramatic basis of Ese Ifa in Yorubaland cannot be divorced from traditional religious ceremonies of African people irrespective of ethnic group. Hence, every aspect of Ifa divination is dramatic, since it contains the elements of art and performance. In facts, Ifa festivals or ritual sacrifices (ceremonies) provide a rich and varied context for dramatic performance.

A typical example of this is the yearly meeting of Ifa priest which is also regarded as a festival in most Yoruba communities. This festival is known as Mole. The festival is very elaborate and usually held for the king. The activities include offerings, chanting of Ifa verse (Ese Ifa) and dancing. The chanting aspect is very dramatic here, in that the chanting is led by someone who is a very good chanter. He chants some verses while the other priest respond by saying "hanin".

This continues and when the chanter misses a line, he is reminded by the people and he immediately corrects himself. Whenever a chanter fails to do this, he is shouted down and another chanter takes over from him and the procession and festival continues like this. The chanting here is accompanied by musical instruments which makes it very dramatic. Apart from this, one sees this festival as a kind of life drama, where there is a main actor; the chanter, and the audience who can be regarded as the common people. The other priests can be regarded as minor characters who also dramatize through dancing, singing, and gesticulating. Thus, one can see a very good dramatic aspect of Ese Ifa in this Mole festival.

In the naming ceremony of a new-born baby, the Babalawo is called to consult Ifa about the destiny and life-style of the child. The Babalawo (chief priest of $I f a$ ) is distinguished from the spectators or congregation present at the ceremony. The mother of the child is also distinguished. The Babalawo and the child's mother can be regarded as chief actors while the crowd can be looked upon as the audience, just as we have in stage drama.

The Ifa priest is distinguished by his insigna of office which are a wristlet of palm fibres or of white, blue and red beads known as "Ide". The second distinction is the horse-tail or "Irukere" and finally his Ifa bag (Apo Ifa). The mother of the child is also distinguished by her dress and by the fact that she has to pass under the consecrated water thrown by the Babalawo on the roof of the house, three times. On each occasion of running out of the house to catch the drippings of the water, the Ifa priest pronounces the child's name. The performance here is very dramatic because there are different actions involved. The ceremony is rounded up by dancing, singing and merriment which in itself its dramatic.

Another very good example of the dramatic context is the consultation of Ese Ifa at a burial ceremony. An example of this is when the death of a popular person occurs, the friends and relations assembled by the death-bed with loud lamentations. The face of the corpse is turned downwards and covered up. Then the majority of them rush into the streets to make a public announcement by crying and singing. The Ifapriest is then sent for who consuls the Ifa divination as to the cause of the death. If If $a$ divination declares the corpse's spirit to be in danger, the If $a$ priest performs certain sacrifices for example, a goat or sheep is sacrificed and the carcass is carried outside the town and deposited at a junction of several roads. After this the Ifa priest performs a purification ceremony by sprinkling the corpse, the room and spectators with the fluid he had prepared. The corpse is later washed and wrapped up for the lying-in-state.

The house of the deceased is lit up and each visitor enters with a cry which may not necessarily be an expression of sorrow. Loud drumming takes place outside the house. Sometimes,professional mourners are employed to make lamentations. Friend and relations of the deceased accompany the bier singing the prises of the dead.

All these performances of chanting, singing, wailing and drumming show a part of drama involved. The actions transmit messages to the people which may be sorrowful like the burial ceremony and which can also be a happy event for example, the naming ceremony. Both performances somehow entertain the crowd like the stage drama which can be comic or tragic. At the same time, they give out different messages to the people just like the stage drama. It is important to also note that an important feature of the religious worship during Ifa divination is dancing. There is hardly any important festival which is not accompanied or followed by dancing. And this, as one knows, is a major characteristic of drama.One can see, therefore, that Ese Ifa, apart from its poetic aspect is also embodied with rich and well-illustrated drama to serve and entertain the people on the whole. 


\section{CONCLUSION}

From the above analysis, it is evident that Ifa plays a prominent role in the life of the Yorubas and their community. In fact, it is the best organized religious system which demonstrates practically all the elements of culture in the Yoruba land.Ifa reveals the future to them, provides explanations to avert the looming danger. Obedience to the injunctions of Ifa leads to prosperity and peaceful coexistence, while disobedience brings doom. This is a testimony to the major role that the transcendent, the metaphysical play and continue to play in the life of the people, despite the presence of the trappings of modernization.

Importantly also, this paper has given a more comprehensive treatment of the complex and rich dramatic aspect of Eselfa which have attracted modern writers of vasty different philosophies and world views. The opinion of this paper is that Ifa Oracle can be used for purposes of cultural tourism, which in turn, is a means of economic development of the country. It is therefore, anticipated that the priests and adherents of traditional religion is general should jealously guard and fight to preserve their exalted citadels in the face of formidable odds.

\section{NoTES}

- All translations into English are mine ( the author)

1. Ifa is a Yoruba oracle, the medium of Orunmila (Yoruba Deity of Wisdom and Omniscience). As it has already been indicated in this paper, Ifa is the philosophy, knowledge, and acts of Orunmila while on earth, constitute a rather all-embracing, comprehensive and uniquely pervasive system. According to Kache Gotrick's (2009:333) comments: Ifa is the Yoruba divination by means of which the Ifa priest communicates with Orunmila, the Yoruba god of wisdom and omniscience. It takes many years of learning to master the Ifa divination and the enormous text necessary to interpret the god's answer, and so, being the authorized channel of communication with Orunmila, an Ifa priest is considered a repository of wisdom. To use Ifa creatively and for the benefit of everybody is equal to making good use of the traditional knowledge and wisdom acquired by the Yoruba peoples over centuries. For a detailed discussion about the role and place of Ifa in Yoruba metaphysics, see Afolabi Epega's Ifa, the Ancient Wisdom(New York: Imole Oluwa Institute, 1977) pp. 39 and 43.

2. Ese Ifaare chapters in Ifa corpus, whose number is so vast that it is hard to determine reliably.

3. Babalawo is the ' father of secrets or diviner in Yoruba. He performs functions ranging from predictions to healing. One can become a Babalawo, according to Olufemi Alofe(2005:77) in one of the following ways: inheritance from father, through apprenticeship and prescription by a priest during a divinatory event. In any case, one must necessarily undergo vigorous training for a number of years. He will perform stipulated rituals in the course of training to qualify for the job. Wande Abimbola (1976) is quoted by Andrew Igenoza (1982:187) that it is a very rigorous training. As a result of its complexities, the trainee has to start his apprenticeship early in life. An extraordinary phenomenon is the claim that whirlwinds (aja) carries someone away for years and is taught Ifa divination and other medicinal practices. Sometimes it last upto seven years. Such individuals usually possess extraordinary powers (D.O.Ogungbile, 1992:188). Other training could be longer as much as twelve years. During the apprenticeship, the trainee learns a vast store of technical and oral poem called $O d u$.

4. Odu are volumes in Ifa corpus.

\section{REFERENCES}

[1] Abimbola, W. (1964).Ifa and Exposition of Ifa Literary Corpus. Ibadan: Oxford University Press (1976). Sixteen Great Poems of Ifa.Ibadan: Oxford University Press.

[2] Adebowale, O. (2000).The Theme of Religion in AlagbaJeremaya.In Odu: A Journal of West African Studies. Ed.Biodun Adeniran. Ile-Ife: Obafemi Awolowo University Press.

[3] Akporobaro, F.B.O. (2012). Introduction to African Oral Literature.Lagos: PrincetonPublishing Co.

[4] Alofe, O.S. (2005). A Biblical Evaluation of the Practice of Divination in Yorubaland. In Insight: A Journal of Religious Studies. Ilishan Remo: Babcock University. 
[5] Bascom, W. (1969). Ifa Divination: Communication Between Gods and Men in West Africa. London: Indiana University Press, Bloomington.

[6] Epega, A. (1977). Ifa, the Ancient Wisdom. New York: ImoleOluwa Institute.

[7] Evans-Pricthard, E. (1965). Theories of primitive Religion. London: OUP.

[8] Farrow, S.S. (1926).Faith, Fancies and Fetish of Yoruba Paganism. London: Society for Promoting Christian Knowledge.

[9] Gleason, J. (1973).A Recitation of Ifa Oracle of the Yoruba.New York: Grossman Publisher.

[10] Gotrick, K. (2009). "Figure of Fantasy: Theatricalizing Devices in Femi Osofisan's AnotherRaft". In Emerging Perspective on Femi Osofisan.Eritea: Africa World Press, Inc.

[11] Idowu, B. (1962) Olodumare: Godin Yoruba Belief. London: Longman Society for Promoting Christian Knowledge.

[12] Igenoza, A. (1982).Prayer, Prophesy, Healing, and Exorcism in Luke, Acts in an AfricanContext. (Unpublished PhD Thesis, University of Manchester).

[13] Lucas, J.O. (1948). The Religions of the Yoruba. Lagos: C.M.S. Bookshop.

[14] Maduakor, Obi. (1987). Wole Soyinka: An Introduction to His Writing. Ibadan: Heinemann Educational Books Nigeria Plc;

[15] Mbiti, J.S. (1975). AnIntroductiontoAfricanReligion. Ibadan: Heinemann Educational Books.

[16] Olatunji, O. (1984). FeaturesofYorubaOralPoetry. Ibadan: University Press Ltd.

[17] Olomola, I. (2000). The Decline of Traditional Deities: A Case Study of Egungun Ado. In Odu: A journal of West African Studies. Ile-Ife; Obafemi Awolowo University Press.

[18] Ogungbile, D.O. (1992). A Comparative Study of Revelation in Aladura Christianity and Divination in Yoruba Religious Tradition in Ile- Ife. (Unpublished M.A. Dissertation, Obafemi Awolowo University, Ile-Ife).

[19] Salamone, F.A. (2010). Hausa Wrestling in Ibadan as an Ethnic Boundary Marker. In Journal of Cultural Studies.Vol. 8, No's, 1, 2 \&3.Eds. Udu Yakubu and Anthonia Makwemosia. Lagos: African Cultural Institute.

[20] Soyinka, W. (1967). Idanre and Other Poems. London: Collings.

[21] Talbot, P.A. (1932). Tribes in Niger Delta: Their Religions and Customs. London: Frank Cass

[22] Udu, Y. (2010). Festivals and Traditional Culture in Yorubaland: Conversation with Oyin Ogunba. In Journal of Cultural Studies.Vol. 8, Nos, 1, $2 \&$ 3.Ed. Udu Yakubu.Lagos: African Cultural Institute.

\section{AUTHOR'S BIOGRAPHY}

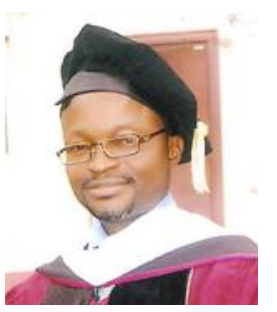

Dr. Olusegun Olu-Osayomi (FIPMD), born of Ekiti parents, is the author of many short stories, books ( one of which is The Secrets of Campus Cults), and biographies of the late Pa M.A. Ajasin, His Eminence S.C. Mbang, Rev.(Dr.) W.A. Badejo (unpublished), Sir (Dr.) E.J. Amana, Prof. P.B.Ikulayo, and Prof.G.B.Onolaja, among others. Dr. Olu-Osayomi, journalist, poet, biographer, literary theorist and critic, is a talented scholar and researcher. He obtained his $\mathrm{PhD}$ in English specializing in Cultural Studies, and he teaches Drama, Poetry, the African Novel, Creative Writing, and (Auto) biographical Studies at the Department of Languages and Literary Studies, Babcock University, Ilisan-Remo, Ogun State, Nigeria. He was formerly the Head of the Department and has won many honours and awards.

Citation: Dr. Olu-Osayomi Olusegun. "Dramatic Aspect of Ese ifa in Yorubaland". International Journal on Studies in English Language and Literature (IJSELL), vol 5, no. 10, 2017, pp. 12-18. doi: http://dx.doi.org/ 10.20431/2347-3134.0510003.

Copyright: () 2017 Authors. This is an open-access article distributed under the terms of the Creative Commons Attribution License, which permits unrestricted use, distribution, and reproduction in any medium, provided the original author and source are credited. 